\title{
ISLAM, KORUPSI DAN GOOD GOVERNANCE DI NEGARA-NEGARA ISLAM
}

\author{
Ahmad Khoirul Umam \\ The University of Queensland, Australia \& The Indonesian Institute (TII), Jakarta \\ e-mail:ahmad_umam@yahoo.com
}

\begin{abstract}
The revitalization of religion function - that some people think - is an effective instrument to fight the cancer of corruption and also the implementation of democratization and liberalization of the market. Value systems, moral teachings and spirituality in religion are considered to be opposite of the corruption characters growing in the contemporary society. The more religiosity of a society leads to the expectation for the lower corruption. However, according to the Corruption Perception Index (CPI) data, we will exactly find a tendency of paradoxical phenomena. For example, in the context of Islamic countries, the high of influence for the Muslims belief to their religion is not directly proportional to the commitment of the corruption eradication in the Muslim populized countries mostly. This phenomenon deserves to be shared reflection, to find the answers of classic questions; why does corruption tend becoming habit of Muslim community who are uphold moral principles and integrity in social life and state? It causes this article to discuss the relationship between religion and corruption in general, and also to elaborate it by dealing with the experience of Islamic countries.
\end{abstract}

\section{[]}

Revitalisasi fungsi agama dianggap oleh sejumlah kalangan sebagai instrumen efektif untuk melawan kanker korupsi, selain pelaksanaan demokratisasi dan liberalisasi pasar. Sistem nilai, ajaran moral, dan dalamnya spiritualitas dalam agama dianggap menjadi antitesa bagi watak korup yang berkembang di tengah masyarakat kontemporer. Semakin tinggi tingkat religiusitas suatu masyarakat, level korupsi diharapkan semakin rendah. Mengaca kepada data Corruption Perception Index (CPI/IPK) kita justru akan menemukan kecenderungan fenomena yang berbeda. Dalam konteks negara-negara Islam misalnya, tingginya pengaruh kepercayaan umat Muslim terhadap agama yang diimaninya ternyata tidak berbanding lurus dengan komitmen pemberantasan korupsi. Fenomena ini patut dijadikan refleksi bersama untuk menemukan jawaban atas pertanyaan klasik; mengapa praktik korupsi cenderung banal alias lumrah dalam tradisi masyarakat Muslim yang dianggap memegang teguh prinsip moral dan integritas dalam kehidupan bermasyarakat dan bernegara? Artikel ini akan mendiskusikan secara general tentang relasi agama dan korupsi, serta mengulasnya dengan mengkontekstualisasikan ke dalam pengalaman negara-negara Islam.

Keywords: Islam, korupsi, good governance, demokratisasi

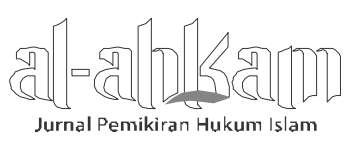




\section{Pendahuluan}

Hampir seluruh agama yang ada dalam sejarah peradaban manusia mengajarkan tentang integritas moral dan menentang praktik korupsi. Islam sebagai agama yang saat ini dianut oleh sekitar 2,1 milyar umat manusia, juga memiliki posisi yang tegas dalam melawan tradisi korupsi. Dalam Islam, korupsi dianggap sebagai tindakan yang tidak sesuai dengan prinsip etika-moralitas (ahlāq alkarimah), keadilan (al-'adālah) dan akuntabilitas (al-amānah). Dalam berbagai studi literatur anti-korupsi, korupsi dianggap sebagai biang keladi merebaknya persoalan-persoalan besar dalam sebuah negara. Dalam konteks politik, korupsi dianggap mampu menghilangkan kepercayaan publik terhadap pemerintah yang pada akhirnya meruntuhkan legitimasi dan memunculkan instabilitas politik pemerintahan yang ada. ${ }^{1}$

Korupsi juga dianggap menjadi penyebab terjadinya disfungsi tata kelola pemerintahan. Dengan merebaknya praktik korupsi, ketidakefisienan dan distorsi terhadap layanan publik dan birokrasi pemerintahan akan terjadi. Akibatnya, dampak destruktif korupsi itu merembet pada aspek perekonomian negara dan masyarakat sehari-hari. Dalam berbagai sumber diyakini bahwa korupsi mampu menghambat investasi dan perkembangan ekonomi, meningkatkan problem pengangguran, ketidakadilan distribusi kesejahteraan rakyat, dan juga memunculkan korosi mental masyarakat. Akibatnya, dalam skala yang lebih luas, korupsi mampu melahirkan kemiskinan terstruktur, konflik horizontal, diskriminasi, dan disparitas ekonomi dalam skala yang sangat besar. ${ }^{2}$

Gejala-gejala destruktif yang ditimbulkan oleh praktik korupsi itulah yang diidentifikasi oleh al-Qur'an sebagai bagian dari tindakan yang merusak (fasād).

\footnotetext{
${ }^{1}$ Donald Bowser, "Corruption Trust, and the Danger to Democratisation in the Former Soviet Union", In the Transition: Essays on Post Communism, ed. David Lovell (London: Ashgate Publishers, 2001). Lihat Donatella Della Porta, "Social Capital, Beliefs in Government and Political Corruption" in Disaffected Democracies: What's Trubling the Trilateral Countries? Eds. Susan Pharr and Robert Putnam (Princeton: Princeton University Press, 2000). Lihat Mitchell Seligson, "The Impact of Corruption on Regime Legitimacy: A Comparative Study of Four Latin American Countries", Journal of Politics, Vol. 64 No. 2, 2002, h. 408-33. Lihat Christopher J. Anderson, and Yuliya V. Tverdova, "Corruption, Political Allegiances, and Attitudes toward Government in Contemporary Democracies", American Journal of Political Science, Vol. 47 No. 1, January 2003, h. 104.
}

2Joseph S Tulchin and Ralph H. Espach (Ed), Combating Corruption in Latin America (Washington DC: Woodrow Wilson Centre Press, 2000).

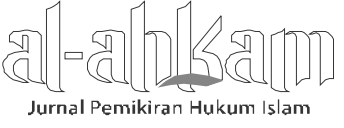


Berbagai ayat dalam al-Qur'an telah menegaskan bagaimana Allah mengutuk perbuatan fasād yang menimbulkan kerusakan dalam tatanan sosial, politik, ekonomi, serta lingkungan. Larangan berbuat kerusakan tentu sudah jamak dipahami dan diceramahkan para khatib dan imam setiap hari di mimbar-mimbar masjid dan majlis ta'lim. Kendati demikian, sebuah pemahaman tidak menjamin hadirnya praktik keseharian yang sesuai dengan apa yang diharapkan.

Masyarakat dapat menyaksikan langsung bagaimana menguatnya proses Islamisasi di berbagai belahan dunia. Simbol-simbol keislaman semakin merangsek ke ruang publik. Kelompok pengajian semakin menjamur, majelis taklim digelar hampir serentak setiap minggunya, jumlah umat Muslim yang menjalankan ibadah haji untuk menyempurnakan keislamannya mengalami lonjakan luar biasa melebihi fenomena tourism di negara-negara maju. Di ranah politik, saluran aspirasi masyarakat mulai dibentuk melalui partai-partai Islam yang kian menjamur. Unsur-unsur Islam telah lebih leluasa masuk ke dalam struktur negara. Bahkan oleh sejumlah kekuatan politik tertentu, tafsir-tafsir hukum Islam telah diterjemahkan langsung dalam bentuk regulasi dan peraturan negara yang sifatnya formal dan mengikat.

Meskipun demikian, seluruh fenomena itu tetap tidak mampu menjawab pertanyaan mengapa praktik korupsi masih saja merajalela di negara-negara Islam. Beragam survey yang dilakukan lembaga riset internasional seperti Transparency International (TI) melalui Corruption Perception Index (CPI)-nya World Bank melalui World Governance Index (WGI)-nya, menunjukkan banyak negara-negara Islam memiliki karakteristik yang relatif sama, yakni tata kelola pemerintahan yang amburadul dan merebaknya praktik korupsi di internal negara tersebut. Korupsi tampak menjadi perilaku wajar (banality) dalam keseharian masyarakat. Korupsi baik dalam skala besar maupun skala kecil terasa menjadi praktik transaksional yang lumrah untuk dijalankan. Pertanyaannya, mengapa praktik korupsi cenderung dianggap sebagai perilaku yang wajar dalam tradisi masyarakat Muslim yang dianggap mampu memegang teguh prinsip moral, integritas dan tanggung jawab? Berbagai upaya pemberantasan korupsi telah dilakukan di berbagai negara berbasis umat Islam, kemudian mengapa agenda anti-korupsi itu cenderung stagnan dan tidak mampu menunjukkan daya gebraknya dalam upaya memperbaiki tata kelola pemerintahan dan kemasyarakatan yang ada? Kompleksitas realitas sosial tersebut lantas menimbulkan pertanyaan selanjutnya, lalu apakah Islam masih layak dianggap compatible sebagai pensuplai aspek nilai dan 
moralitas publik untuk memperkuat tradisi good governance di negara-negara berbasis umat Islam?

Tulisan ini berusaha untuk mengurai perdebatan lama terkait kajian tentang relasi agama dan korupsi. Untuk mengupas topik tersebut, tulisan ini sepenuhnya menggunakan tinjauan pustaka melalui telaah materi dan data-data sekunder di berbagai buku dan jurnal, untuk mencermati dinamika perkembangan sosial, perdebatan teoritik, hingga contoh-contoh data mutakhir terkait relasi agama dan pemberantasan korupsi di negara-negara berbasis masyarakat Islam.

\section{Kompleksitas Definisi Korupsi}

Mengurai beberapa pertanyaan di atas, terlebih dulu kita masuk dalam ranah dasar untuk memahami konteks makna korupsi yang akan diulas dalam artikel ini. Harus diakui, salah satu kesulitan yang sering ditemui dalam studi korupsi dan tata kelola pemerintahan adalah tentang pendefinisian korupsi dan identifikasi penyebab terjadinya praktik korupsi itu sendiri. Hal ini tak lain dikarenakan oleh luasnya pemahaman dan varian dalam kajian anti-korupsi. Beragam tawaran definisi dan identifikasi penyebab terus bermunculan berdasarkan sudut pandang yang beragam. Dilihat dari bentuk transaksinya, korupsi dapat berupa praktik penyuapan, pemerasan, penyalahgunaan informasi, penipuan dalam proses pengadaan barang, penggelapan dana, pencucian uang, hingga politik uang. Sementara jika dicermati dari sisi aktor dan wilayah terjadinya korupsi, jenis korupsi dapat terderivasi ke dalam berbagai jenis laiknya korupsi birokrasi yang melibatkan para birokrat dalam struktur pemerintahan, korupsi politik melibatkan aktor-aktor politik terkait dengan political financing untuk partai-partai mereka, korupsi legislatif merupakan jenis lain yang dilakukan dalam ruang demokrasi dimana praktik vote-buying dan money politics juga termasuk di dalamnya. Sementara jika ditilik dari level korupsi skala ancaman destruksinya besar atau kecil, maka entitas korupsi dapat dipecah sebagai grand corruption dan petty corruption. Pemahaman grand corruption merujuk pada praktik korupsi dalam skala besar yang dilakukan elite politik, pemerintahan, militer (the big fishes) yang memiliki efek destruktif terhadap hancurnya anggaran negara, penegakan hukum, jatuhnya legitimasi pemerintahan, dan rapuhnya struktur ekonomi negara secara massif dan sistematis. Sementara petty corruption merujuk kepada praktik korupsi kecil laiknya praktik suap di birokrasi pemerintahan, penyalahgunaan dana bantuan sosial, suap layanan publik dan lainnya. 
Rose-Ackerman berusaha mendefinisikan dan mengidentifikasi penyebab dan dampak korupsi terhadap berbagai sektor yang ada, misalnya korupsi dapat didefinisikan dan didentifikasi penyebab dan dampaknya terhadap sektor perekonomian Negara. ${ }^{3}$ Sementara para peneliti lain seperti Bowornwathana dan Wescott dan Park telah fokus pada pendefinisian dan kajian korupsi dari aspek hukum dan budaya birokrasi. ${ }^{4}$ Definisi korupsi secara berbeda juga ditawarkan ketika terminologi dan fenomenanya ditilik dari aspek sosial budaya, etika keberagamaan, dan sejarah bangsa-bangsa. ${ }^{5}$

Jika didefinisikan berdasar aspek hukum, maka definisi korupsi adalah tindakan yang melanggar norma-norma hukum yang telah tertuang dalam aturan perundangan terkait tindak kejahatan korupsi. Problemnya, setiap negara memiliki aturan hukum dengan pendefinisian korupsi yang beda antara satu negara dengan negara lainnya. Ketika sudut pandang hukum diganti dengan kacamata budaya, kompleksitas definisi korupsi lebih tidak terukur. Sebab konsep etis, makna suap, dan persepsi korupsi antara negara benar-benar berbeda dan jauh lebih kompleks. Apa yang dianggap sebagai perilaku koruptif dan tidak etis dalam suatu budaya masyarakat yang satu, bisa juga dipandang sebagai perilaku atau transaksi rutin yang normal dan wajar dalam konteks budaya masyarakat yang lain. Di sejumlah negara-negara Asia misalnya, prinsip resiprositas yang tertuang dalam kebiasaan pemberian hadiah, yang biasanya dikategorikan sebagai suap dan perilaku korup dalam budaya Barat misalnya, justru telah memainkan peranan

${ }^{3}$ Susan Rose-Ackerman, "The Political Economy of Corruption" in Kimerbly Ann Elliott (Ed), Corruption and the Global Economy (Washington DC: Institute for International Economics, 1997), h. 31-60. Lihat Wayne Sandholtz and William Koetzle, "Accounting for Corruption: Economic Structure, Democracy, and Trade", International Studies Quarterly, Vol. 44 (1), March 2000, h. 31-50. Lihat D Treisman, "The causes of corruption: A cross-national survey", Journal of Public Economics, Vol. 76 No. 3, 2000, h. 399-457. Lihat Montinola GR and Jackman RW, "Sources of Corruption: A Cross-Counrty study", British Journal of Political Science, Vol. 31, 2002, h.147-170.

${ }^{4}$ Bidhya Bowornwathana \& Clay G. Wescott, "Comparative Governance Reform in Asia: Democracy, Corruption and Government Trust", International Public Management Review, Vol. 8 No. 2, 2007. Lih. Park, H., "Determinants of Corruption: A Cross-National Analysis", Multinational Business Review, Vol. 11 No. 2, 2003, h. 29-48.

${ }^{5}$ Holmes L., "Corruption and the Crisis of Post-Communist State", Crime, Law \& Social Change, Vol. 27, 1997, h. 275-297. Lihat Wayne Sandholtz and William Koetzle, "Accounting for Corruption: Economic Structure, Democracy, and Trade", International Studies Quarterly, Vol. 44 No. 1, March 2000, h. 31-50. Lihat Tageepera R., "Baltic Values and Corruption in Comparative Contex", Journal of Baltic Studies, Vol. 33 No. 3, 2002, h. 243-258. Lihat Ahmad Khoirul Umam, Kiai dan Budaya Korupsi di Indonesia (Semarang: Rasail, 2006).

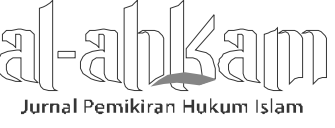


penting dalam hubungan antara para penguasa politik dan masyarakat sebagai simbol penghormatan dan ucapan terima kasih. ${ }^{6}$

Karena itu, Bank Dunia7 jauh-jauh hari telah menggarisbawahi bahwa 'the definition and causes of corruption are always contextual, rooted in a country's policies, bureaucratic traditions, political development, culture, and social history". Definisi korupsi harus dikontekstualisasikan dengan corak budaya, kebijakan negara, dan akar sejarah sosial masyarakat masing-masing. Meskipun tidak terdapat konsensus baku yang dapat menjadi rujukan tunggal dalam mendefinisikan terminologi korupsi, tetapi banyak pihak bersepakat di titik tengah dengan memahami korupsi sebagai penyalahgunaan jabatan publik untuk memperkaya pribadi dan menguntungkan kepentingan kelompoknya hingga merugikan kepentingan umum. ${ }^{8}$ Untuk membatasi perdebatan ini, Asian Development Bank (ADB) dan juga Transparency International (TI) juga menawarkan definisi 'minimalis' untuk memahami korupsi sebagai "the use and abuse of public power for personal material gains as well as political benefits". 9 Jadi pemahaman korupsi lebih ditekankan pada aspek penyalahgunaan kekuasaan publik yang menguntungkan kepentingan individu atau kelompok.

Praktik korupsi memiliki beragam tipologi. Sayyid Husein Alatas ${ }^{10}$ membagi tipologi korupsi itu dalam enam kategori. Pertama, transcative corruption, yakni praktik korupsi yang melibatkan persetujuan antara penyuap dan pemberi suap yang didasarkan pada keuntungan bersama yang disepakati. Kedua, extortive corruption, yakni praktik korupsi yang melibatkan praktik pemerasan yang diarahkan untuk menghindari konsekuensi hukum bagi mereka yang terlibat dalam kasus-kasus tertentu. Ketiga, investive corruption, yakni praktik korupsi yang dimulai dengan memberikan janji untuk mendapatkan sesuatu sebelum melakukan hal-hal yang dianggap melanggar norma hukum yang ada. Keempat, nepotist corruption,

\footnotetext{
${ }^{6}$ Susan Rose-Ackerman, Corruption and Government: Causes, Consequences and Reform (New York: Cambridge University Press, 1999).

${ }^{7}$ Lihat Data Bank Dunia Tahun 2002.

8Lihat Transparancy International Tahun 2003; Lihat Arvind K. Jain, "Corruption: A Review", Journal of Economic Surveys, Vol. 15 No. 1, 2001.

${ }^{9}$ Azumardy Azra, "Islam, Corruption, Good Governance, and Civil Society: The Indonesian Experience”, Pluto Journals, 2007.

${ }^{10}$ Syed Hussein Alatas, Corruption: Its Nature, Causes and Consequences (Avebury: Aldershot and Brookfield VT, 1990).
}

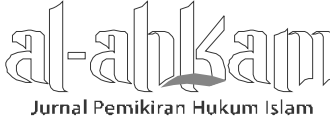


yakni praktik korupsi yang dilakukan dengan menegasikan aspek profesionalitas dan integritas pihak lain dan lebih menekankan pada unsur kedekatan, pilih kasih atau favouritism terutama mereka yang memiliki hubungan kekeluargaan, praktik ini biasanya mendelegitimasi proses fit and proper test yang diharapkan menghadirkan proses seleksi yang professional dan objektif. Kelima, autogenic corruption, yakni praktik korupsi yang mengambil keutungan dari posisi seseorang sebagai bagian integral dari sebuah sistem melalui pembocoran informasi, kebijakan, hingga memberikan perlakuan khusus atas hal-hal yang seharusnya dirahasiakan. Fenomena semacam ini yang dikabarkan marak terjadi di Mahkamah Konstitusi (MK) terutama dalam kasus yang menimpa mantan Ketua MK Akil Muchtar. Keenam, supportive corruption, yakni praktik korupsi yang dilakukan dengan memberikan perlindungan hukum dan politik kepada pihak-pihak yang bermasalah di dalam lingkaran kekuasaan. Kesemua tipologi korupsi itu tidak hanya terjadi di level institusi publik seperti halnya birokrasi dan pemerintahan, melainkan juga di ranah privat atau swasta yang dianggap mampu mengacaukan corporate governance, baik dalam skala besar (big corruption) maupun praktik korupsi ringan (petty corruption) laiknya pungutan liar dalam birokrasi, layanan publik, dan lainnya. Artikel ini tidak akan spesifik membahas aspek dan tipologi korupsi sebagaimana yang tertera di atas, tetapi akan membahas praktik korupsi secara general yang kian mengakar dan membudaya dalam tradisi masyarakat global.

\section{Posisi Islam dalam Jihad Melawan Korupsi}

Dalam konteks literatur Islam dan perdebatan hukum Islam, korupsi acapkali diidentikkan dengan praktik suap dalam literatur-literatur khasanah Islam klasik. Suap dalam bahasa Arab adalah rishwah atau rushwah, yang berasal dari kata arrìsha, yang artinya sebuah tali yang menyambungkan sesuatu ke air. Dalam kitab An-Nihāyah-nya Ibn Kathīr, disebutkan rishwah atau rushwah memiliki tasrïf-an kata (perubahan bentuk) seperti wartasha yang diartikan sebagai kerja mengambil, arshāhu (memberikan sesuatu padanya) bermakna memberikan hadiah, atau menjadikan padanya sesuatu, dan rāshu (memberi uang suap) bermakna memberinya suap. Kata jamak rūsha seringkali dicontohkan dalam kalimat "rashawtuhu rashwa": aku memberinya suap. Dalam al-Misbah, kata rishwah yang bentuk pluralnya rīsha didefinisikan sebagai sesuatu yang diberikan seseorang kepada hakim, pemimpin, atau pihak lain, dengan suatu perjanjian bahwa perkara atau urusannya diputuskan berdasarkan keinginan orang yang memberikan suap.

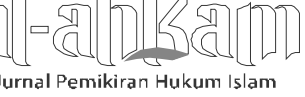


Al-Rāshī adalah orang yang memberikan sesuatu yang batil, sedangkan murtashī adalah orang yang menerima. Al-Rā'shī adalah perantara di antara keduanya, sehingga Rasulullah Muhammad melaknat ke semua pihak ini (La'nat Allāh 'ala 'lrāshī wa 'l-murtashî̀), hal itu kemudian kembali dipertegas bahwa penyuap dan yang disuap serta pihak yang berada di antara keduanya (broker) akan masuk neraka (al-rāshī wa I-murtashī wa baynahumā fi ' l-nār). ${ }^{11}$

Ajaran spiritualitas dalam Islam mengajak umat serta para pemimpin umat untuk senantiasa menjadi umat yang moderat (wasāț). Kemoderatan itu tidak hanya diwujudkan dalam proses negosiasi kepentingan dalam ranah tarik ulur politik dan kekuasaan, tetapi juga dalam kehidupan sehari-hari. Islam mengajak umatnya untuk tidak suka menimbun dan menumpuk-numpuk harta kekayaan. Akumulasi kekayaan yang tidak terdistribusikan dengan baik justru akan menimbulkan fitnah dan resistensi sosial. Karena itu, Islam mengajarkan kepada umatnya untuk mendonasikan setiap kelebihan harta yang dimiliki kepada pihakpihak yang miskin, terpinggirkan, tertindas, dan mereka yang berhak menerima sebagaimana yang telah diajarkan dalam tatanan fikih. Karena itu praktik filantropi benar-benar mengakar dalam tradisi keislaman, hal itu ditunjukkan adanya perintah zakat, infāq, șadaqah, dan lainnya.

Kendati demikian, ajaran Islam menggarisbawahi apa-apa yang didistribusikan itu haruslah diperoleh dari jalan yang baik (tayyib) dan halal (lawful). Akumulasi harta yang tidak diperoleh dengan jalan yang baik dan halal dipercaya akan mendatangkan balā' bagi masyarakat. Karena itu, spiritualitas dalam tradisi keislaman sangat menentang watak dan karakter individu yang rakus, yang hendak menyerobot semua hak orang lain untuk diakumulasikan di bawah nama dan kekuasaannya. Di sinilah, kontrol pribadi menjadi penting untuk mengantisipasi berkembangnya watak tamak dan rakus yang semakin mengaburkan batas identitas sebagai manusia maupun hewan. Karena itu, Islam mengajak umatnya untuk ber-jihād atau bersungguh-sungguh untuk mampu menahan diri untuk tidak masuk dalam jebakan nafsu ketamakan. Ajaran semacam ini merupakan fondasi dasar bagi pembangunan integritas manusia. Semakin tinggi etika dan moralitas dijalankan, semakin tinggi pula kualitas integritas yang dihasilkan.

\footnotetext{
11Lihat: Abdul Ghani ibn Ismail an-Nablusi, Hukum Suap dan Hadiah (Jakarta: Maktabah al-Qur'an, 2003). 
Ketika integritas sudah teruji secara publik, maka seseorang itu akan menjadi ikon yang baik (uswah hasanah) bagi masyarakat di sekelilingnya.

Jika para pemimpin negara yang seringkali memamerkan simbol-simbol kealiman dalam tradisi spiritualitas keagamaan itu benar-benar dapat menjadi uswah hasanah, maka perubahan watak dalam struktur negara dan pemerintahan diharapkan dapat terjadi lebih cepat. Para pemimpin negara-negara Muslim tidak boleh lupa bahwa reformasi di tubuh pemerintahan mereka cenderung masih bersifat struktural dan instrumental, sementara perbaikan karakter budaya dan integritas personil dan kelembagaan masih membutuhkan kerja ekstra keras yang melibatkan komitmen serta keseriusan seluruh komponen yang ada. Kualitas reformasi di masing-masing negara akan sangat dipengaruhi oleh kualitas integritas pemimpin mereka. Logika sederhana tentang "membersihkan lantai kotor tidak bisa menggunakan sapu yang kotor" dan "membersihkan dinding kotor tidak bisa dimulai dari bawah, melainkan harus dari atas" merupakan nasihat lama yang masih sangat relevan untuk diterapkan dalam upaya memperbaiki kualitas pemerintahan yang ada. Teladan dari seorang pemimpin dianggap dapat menghadirkan kekuatan moral untuk menggerakkan perubahan secara massif dan simultan di dalam berbagai lingkup kekuasaan. Pemimpin yang berintegritas akan memiliki legitimasi moral untuk mengingatkan (tawșiyah) pihak-pihak yang masih di luar etika dengan cara memberikan contoh-contoh sikap dan perilaku yang berintegritas (maw'izah hasanah) dan juga melalui diskusi-diskusi yang beradab dan mencerahkan (mujādalah). Karena itu, ajaran-ajaran spiritualitas keislaman dan juga perintah akan hadirnya pemimpin yang berintegritas itu benar-benar sesuai (compatible) dengan prinsip-prinsip dasar anti-korupsi dan good governance yang dikampanyekan banyak lembaga-lembaga donor internasional untuk menciptakan hadirnya tata kelola pemerintahan yang baik.

Karena itu, salah satu poin dalam laporan Global Integrity ${ }^{12}$ menyimpulkan bahwa pembentukan lembaga spesial anti-korupsi bukanlah solusi utama dalam agenda pemberantasan korupsi yang sistemik, efektif, dan komprehensif. Komitmen dan keseriusan politik seorang pemimpin-lah yang dianggap sebagai faktor terpenting dalam menentukan keberhasilan pemberantasan korupsi dalam suatu negara. ${ }^{13}$ Dalam bahasa J. Quah disebutkan "Without political will of the top political

\footnotetext{
12Lihat Laporan Global Integrity, 2011.

${ }^{13}$ R. Klitgaard, Controlling Corruption (California: University of California Press, 2008).
}

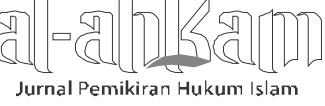


leader, anti-corruption is nothing".14 Jika pemimpin setengah hati, artinya akar-akar korupsi tetap dibiarkan terus menjalar, akibatnya lembaga anti-korupsi tidak ada bedanya dengan lembaga pemadam kebakaran yang tenaga, sumber daya, dan konsentrasinya hanya difokuskan pada percikan-percikan api kecil yang bermunculan, sementara potensi kebakaran yang jauh lebih dahsyat dibiarkan begitu saja menyebar dan mengakar dalam sistem politik dan pemerintahan yang pada saatnya mampu menenggelamkan negara dan mesin anti-korupsi itu sendiri. Fenomena itulah yang dimaksud oleh Zainal Arifin Mochtar sebagai 'efek treadmill' pemberantasan korupsi yang masih berlanjut hingga saat ini. ${ }^{15}$ Berbagai upaya mulai dari pembentukan lembaga, perumusan produk hukum, kebijakan reformasi birokrasi dengan penggelontoran dana yang tak terhitung jumlahnya, dan juga sinkronisasi aturan hukum telah dilakukan semua. Seolah-olah bangsa ini telah berlari begitu kencang melawan korupsi, tapi sejatinya kita masih berdiri di posisi yang sama, berlari di atas pijakan semula, yang artinya kita mandeg dan juga stagnan.

Posisi tegas Islam yang menentang praktik korupsi itu juga diharapkan dapat menjadi doktrin solutif untuk mengarahkan perilaku dan moralitas masyarakat untuk tidak korup. Tidak hanya Islam, elemen agama-agama lain juga digunakan sejumlah pemerintahan sebagai instrument untuk memerangi perilaku korup yang berkembang di masyarakatnya. Dalam catatan Marquette, disebutkan misalnya di negara bagian Zamfara, Nigeria, pemerintah lokal menyerukan kepada para imam atau pemuka agama Islam untuk bersinergi dengan agenda pemberantasan korupsi pemerintahan Nigeria melalui peningkatan standar moralitas umat setempat ${ }^{16}$ Siti Faridah Abdul Jabbar dalam papernya yang berjudul "Corruption: Devolving into the muddy water through the lens of Islam" juga menegaskan positioning Islam dalam agenda pemberantasan korupsi dengan harapan negaranegara berbasis masyarakat Islam dapat mengintesifkan perang melawan korupsi. ${ }^{17}$

\footnotetext{
14J. Quah, "Combating Corruption in the Asia-Pacific Countries: What Do We Know and What Needs to be Done?",International Public Management Review, Vol. 10 (1), 2009, h. 5-29.

15Zainal Arifin Mochtar, "Efek Treadmill Pemberantasan Korupsi”, Kompas, 11 Desember 2009.

16Heather Marquette, "Finding God of Moral Disegagement in the Fight Against Corruption in Developing Countries? Evidence from India and Nigeria", Public Admin. Dev, Vol.32, 2012.

${ }^{17}$ Siti Faridah Abdul Jabbar, "Corruption: Delving into the Muddy Water Through the Lens of Islam", Journal of Financial Crime, Vol. 20, Issue 2, 2013.
} 
Tidak sedikit negara-negara Islam yang saat ini berusaha mengintesifkan peran Masjid, pendidikan Islam laiknya pesantren dan juga para pemuka agama Islam untuk mengajak seluruh umatnya guna mempertegas posisi dalam memerangi korupsi. Pelibatan para tokoh-tokoh itu dilakukan dengan harapan dapat membuat agenda anti-korupsi berjalan lebih efektif, membumi, dan sistematis. Di Indonesia, pemerintah juga mengintensifkan peran organisasi-organisasi sosial keagamaan seperti Nahdlatul Ulama (NU) dan Muhammadiyah untuk membantu mengintensifkan perlawanan terhadap sikap korupsi. Walaupun upaya pemberantasan korupsi semakin intensif dilakukan dengan mengintensifkan pendidikan dan peningkatan standar moral masyarakat melalui program-program keagamaan, namun negara-negara Muslim yang mengidap penyakit korupsi itu tidak banyak menemukan adanya perubahan. Praktik korupsi masih saja terus berlangsung, semakin sistematis, terstruktur, dan semakin merusak pilar-pilar negara dan pemerintahan yang ada.

\section{Banalitas Korupsi di Negara-negara Muslim}

Fakta korupsi di negara-negara Muslim merupakan ironi besar sekaligus fakta yang harus dijelaskan secara ilmiah. Pengukuran terhadap tingkat korupsi di suatu negara telah dilakukan oleh berbagai lembaga riset internasional. Transparency International (TI) merupakan lembaga berbasis di Berlin, Jerman yang rutin merilis hasil indeks persepsi korupsi atau Corruption Perception Index (CPI) negara-negara setiap tahunnya. Sejak tahun 2012, TI menggunakan instrument riset yang baru, dimana penentuan level CPI juga melibatkan 12 lembaga bergengsi seperti Economist Intelligent Unit, Freedom Institute, Global Insight, Political \& Economic Risk Consultancy, Political Risk Services, World Economic Forum, termasuk instrumennya Wolrd Bank melalui World Bank Governance Index (WGI). Dalam riset di masing-masing negara, mereka dibantu oleh para stakeholders dari negara-negara setempat serta kalangan pemerintah di tiga cabang kekuasaannya antara lain legislatif, eksekutif, yudikatif. Pengumpulan data di masingmasing negara itu juga melibatkan kalangan akademisi, non-government organization (NGO), civil society, media, pelaku usaha dan lainnya sebagai sumber informasi kunci agar akurasi dan validitas informasi yang diperoleh dapat dipertanggungjawabkan, dan tingkat error analysis-nya bisa ditekan sedemikian rupa. Bagaimanapun, potensi kelemahan pasti ada dalam setiap metodologi, tetapi instrumen tersebut setidaknya dapat membantu kita untuk mendekati objektivitas 
fakta yang ada. Adapun indeks persepsi korupsi di negara-negara Islam per tahun 2014 sebagai berikut:

Table 1.

Indeks Persepsi Korupsi (IPK) sebagian Negara-negara Berbasis Umat Islam

\begin{tabular}{clcclc}
\hline No. & \multicolumn{1}{c}{ Negara } & IPK & No. & \multicolumn{1}{c}{ Negara } & IPK \\
\hline 1 & Uni Emirates Arab & 70 & 14 & Indonesia & 34 \\
2 & Qatar & 69 & 15 & Pakistan & 29 \\
3 & Malaysia & 52 & 16 & Kazakhstan & 29 \\
4 & Saudi Arabia & 49 & 17 & Azerbaijan & 29 \\
5 & Bahrain & 49 & 18 & Lebanon & 27 \\
6 & Jordan & 49 & 19 & Iran & 27 \\
7 & Oman & 45 & 20 & Syria & 20 \\
8 & Turki & 45 & 21 & Yemen & 19 \\
9 & Kuwait & 44 & 22 & Libya & 18 \\
10 & Tunisia & 40 & 23 & Iraq & 16 \\
11 & Maroko & 39 & 24 & Sudan Selatan & 15 \\
12 & Mesir & 37 & 25 & Afganistan & 12 \\
13 & Brunei Darusalam & No data & 26 & Palestina & No data \\
\hline
\end{tabular}

Data Indeks Persepsi Korupsi (IPK) yang dikeluarkan oleh Transparency International (TI) itu diolah dengan metode baru yang berbeda dengan hasil survey sebelum tahun 2012. Sejak 2012, IPK diperoleh dengan mengkontekstualisasikan hasil survey ke dalam perubahan skala nilai dari 0 untuk kategori indeks terkorup dan 100 untuk kategori terbersih. Berdasarkan data di atas, dapat dilihat bahwa hanya tiga negara berbasis umat Islam yang memiliki indeks persepsi korupsi yang melampaui batas tengah (50) dari skala nilai yang diterapkan (0-100). Ketiga negara itu antara lain Uni Emirates Arab, Qatar dan Malaysia.

Indonesia sendiri masih berada di peringkat 114 dari 175 negara yang disurvei, yakni dengan skor IPK 34. Oleh pemerintah, capaian angka itu tetap dianggap sebagai hasil gemilang mengingat pada tahun 2011, Transparency International sempat menempatkan Indonesia pada peringkat delapan besar dalam kategori perubahan paling progresif (the most progressive change) dalam pemberantasan korupsi dibandingkan sekitar 170-an negara yang disurvei. Menurut data TI kala itu, dalam rentang tahun 2004 hingga 2011 dimana metode survey masih menggunakan skor 0 untuk kategori paling korup dan 10 untuk kategori paling bersih, perubahan CPI paling signifikan di dunia terjadi di Georgia dengan peningkatan IPK sebesar 2,3 
poin, kemudian Polandia (1,9 poin), lalu diikuti Qatar, Macedonia, Uni Emirat Arab dan Uruguai di level perubahan yang sama (1,6 poin), hingga Bangladesh (1,4 poin). Sementara posisi perubahan IPK Indonesia waktu itu setara dengan perubahan yang terjadi di Korea Selatan (1,1 poin) dan Serbia (1 poin). Bahkan posisi Indonesia jauh berada di atas negara-negara BIRC seperti Brazil, India, Rusia, dan China yang selama ini dianggap sebagai the darling of global investment.18 $\mathrm{Di}$ atas 'sanjungan' yang menggembirakan itu, harus tetap disadari bahwa IPK Indonesia masih tetap bertengger di angka 3,2 pada tahun 2011 atau di angka 34 pada tahun 2014 yang berarti masih sangat jauh dari peringkat bersih.

Jadi, lebih dari 24 negara yang diidentifikasi berbasis umat Islam tampak memiliki problem akut yang sama dalam agenda pemberantasan korupsi. Tentu sebab yang dihadapi oleh masing-masing negara itu sangat beragam. Negaranegara Timur Tengah seperti Uni Emirat Arab, Qatar, Jordan, Oman, Saudi Arabia, Bahrain atau Kuwait jelas memiliki karakteristik yang berbeda di banding Yaman, Syria, Libya, atau negara-negara Afrika seperti Mesir, Maroko, Aljazair, dan lainnya. Begitu pula Indonesia, Malaysia, Brunei juga memiliki katarakteristik berbeda. Perbedaan itu tidak hanya ditunjukkan oleh aspek stabilitas politik internal, kualitas perkembangan ekonomi, kualitas sumber daya manusia, gross domectic product (GDP)-nya, dan lain sebagainya. Tetapi dalam aspek pelaksanaan dan penggunaan simbol-simbol keagamaan di ranah publik, negara-negara itu memiliki trend yang relatif sama. Di mana Islam diposisikan sebagai sumber nilai dan ajaran moral-spiritual yang diharapkan dapat memperbaiki konsisi sosial kemasyarakatan mereka.

Tren serupa juga ditemukan oleh S. Douglas Beets dalam artikelnya yang berjudul Global Corruption and Religion: An Empirical Examination ${ }^{19}$ yang didasarkan pada olahan data Corruption Perception Index (CPI) atau Indeks Persepsi Korupsi (IPK) yang dirilis Transparency Internasional pada tahun 2003. Dalam survey yang kala itu melibatkan 133 negara, Beets berusaha mencari relasi antara aspek agama dan fenomena praktik korupsi di dunia. Dalam klasifikasi IPK berbasis latar belakang agama tersebut ditemukan trend sebagai berikut:20

18Lihat Data Transparency International, 2012.

${ }^{19}$ S. Douglas Beets, “Global Corruption and Religion: An Empirical Examination”, Journal of Global Ethics, Vol. 3 No. 1, 2007.

20 Ibid.

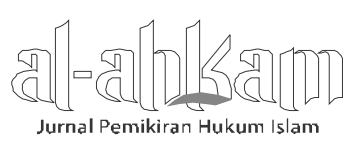


Ahmad Khoirul Umam

Table 2.

Indeks Persepsi Korupsi (IPK) Negara-negara Berbasis

Agama-agama Dominan di Dunia

\begin{tabular}{|c|c|c|c|c|c|c|c|c|c|}
\hline $\begin{array}{l}\text { Kategori } \\
\text { Kepercayazan }\end{array}$ & Budha & Kristen & Hindu & ISam & Yahudi & $\begin{array}{l}\text { Agam } \\
\text { alain }\end{array}$ & $\begin{array}{l}\text { Non- } \\
\text { Agama }\end{array}$ & $\begin{array}{c}\text { Tidak } \\
\text { Dominan }\end{array}$ & $\begin{array}{c}\text { Rata } \\
\text { rata }\end{array}$ \\
\hline RatarataIPK & 5.0 & 5.0 & 3.6 & 3.3 & 7.0 & 3.3 & 3.8 & 3.0 & 4.2 \\
\hline $\begin{array}{l}\text { Pentingnya } \\
\text { aspekagama } \\
\text { bagipublik } \\
\text { (\%) }\end{array}$ & 18.0 & 58.0 & 92.0 & 80.1 & $\begin{array}{l}\text { No } \\
\text { data }\end{array}$ & $\begin{array}{l}\text { No } \\
\text { data }\end{array}$ & 24.5 & 52.5 & 58.2 \\
\hline $\begin{array}{l}\text { AspekKe- } \\
\text { bebasan } \\
\text { beragama }\end{array}$ & 4.6 & 2.6 & 5.0 & 504 & 3.0 & 2.5 & 4.0 & 3.6 & 3.6 \\
\hline $\begin{array}{l}\text { GDPper } \\
\text { Capita(\$) }\end{array}$ & $\begin{array}{c}1321 \\
6\end{array}$ & 13246 & 6.770 & 5546 & 19000 & 3388 & 6843 & 6225 & $\begin{array}{c}984 \\
9\end{array}$ \\
\hline $\begin{array}{l}\text { Jumlah } \\
\text { Negara }\end{array}$ & 7 & 64 & 2 & 34 & 1 & 4 & 7 & 14 & - \\
\hline
\end{tabular}

Dalam riset tersebut, Beets mengelompokkan setidaknya ada 34 negara yang memiliki banyak masyarakat Islam di dalamnya. ${ }^{21}$ Banyak negara "Stan" seperti Tajikistan, Uzbekistan dan lainnya yang notabene pecahan Uni Soviet dimasukkan dalam pengelompokan tersebut. Pada saat itu, dari ke-34 negara berbasis Muslim yang ada, hanya Oman $(6,3)$ dan Bahrain $(6,1)$ yang mampu melampaui batas ratarata IPK. Sementara itu, setidaknya ada sepuluh negara yang masuk kategori moderat yang berada di posisi tengah yakni sekitar angka rata-rata $(5,1)$ dalam skala IPK 0 sampai 10. Sementara yang 24 negara Muslim lainnya, masuk dalam kategori negara dengan tingkat korupsi yang tinggi dengan rata-rata IPK sekitar 2,5 saja. Jika dilihat dari aspek GDP per capita, negara-negara yang memiliki tingkat korupsi yang sedang atau moderat umumnya memiliki GDP per capita sekitar $\$ 11.500$, sementara negara-negara Muslim yang memiliki tingkat korupsi yang tinggi umumnya memiliki GDP per capita yang rendah dengan rata-rata sekitar $\$ 3000$.

Sejumlah 34 negara berbasis umat Islam tersebut, hampir semua negara memiliki spirit dan semangat yang sama untuk memberantas korupsi, dimana

21 Ibid.

208 || Volume 24, Nomor 2, Oktober 2014

Jurnal Pemikiran Hukum Islam 
nilai-nilai Islam tetap dianggap sebagai aspek keagamaan yang fundamental. Dalam tabel di atas terlihat bahwa aspek agama dianggap sangat penting $(80,1 \%)$ dalam 34 negara-negara berbasis umat Islam yang disurvei tersebut. Standar ukuran yang digunakan untuk menilai aspek pentingnya agama dalam suatu negara itu diambil dari Pew Global Attitute Project dimana penilaian publik yang ditanya "seberapa penting agama dalam kehidupan Anda? (how important is religion in your life?) untuk kemudian dijabarkan dalam bentuk prosentase penilaian. ${ }^{22}$ Dibandingkan dengan negara-negara yang memiliki basis agama Kristen dan Budda, masyarakat Islam memiliki tingkat kepercayaan yang lebih tinggi terhadap aspek keagamaan yang mereka yakini. Tetapi, meskipun kepercayaan mereka sangat tinggi, hasil dan out put-nya tetap menunjukkan adanya varian dan perbedaan trend yang mencolok.

Tabel di atas itu juga menyelipkan pelajaran tersendiri bahwa jika memang tidak ada relasi yang kuat antara ketaatan dan keyakinan beragama dengan praktik korupsi, maka ada kecenderungan lain yang kiranya menjadi faktor penentu mengapa suatu negara dianggap berhasil menekan korupsi dan yang lain tidak berhasil. Faktor pembeda itu dapat dilihat dari aspek GDP per Capita yang menunjukkan perbedaan kualitas pembangunan ekonomi di masing-masing negara. Negara-negara berbasis agama Hindu dan Islam yang memiliki tingkat keyakinan tinggi terhadap agama tapi GDP per kapitanya rendah cenderung menghasikan IPK yang juga rendah. Sementara negara-negara yang berbasis masyarakat Buddha dan Kristen yang tingkat kepercayaan mereka terhadap agama mereka tidak begitu dominan, tetapi GDP per capita mereka tinggi, maka kecenderungan yang ada tingkat korupsi mereka rendah. Asumsi ini harus diberi tanda pengecualian dalam konteks agama Yahudi, sebab hanya ada satu negara yang disurvei di sini yakni Israel. Sebuah negara kecil tetapi banyak para penganutnya yang menguasai modal dan peta perekonomian dunia sehingga mampu melahirkan GDP per capita yang tinggi (\$19.000) dan out put IPK-nya juga tinggi (7.0). Dalam konteks ini, Beets, ${ }^{23}$ tampaknya ingin menggarisbawahi bahwa 10 negara berbasis umat Islam yang CPI-nya termasuk baik dan moderat itu karena dipengaruhi oleh peningkatan GDP yang salah satunya dipicu oleh semakin kuatnya integrasi negara-negara tersebut dalam sistem perdagangan global

\footnotetext{
22Lihat: Pew Global Attitute Project Tahun 2003.

${ }^{23}$ S. Douglas Beets, “Global Corruption and Religion, An Empirical Examination”
}

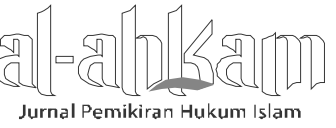


dengan mengoptimalkan komoditas perdagangan masing-masing negara. Tesis yang dibangun adalah, semakin suatu negara terintegrasi dengan sistem perdagangan global, maka negara itu akan semakin bersih dari korupsi. Banyaknya korporasi asing yang berinteraksi dengan pasar domestik akan meningkatkan tuntutan akan hadirnya akuntabilitas dan transparansi dalam setiap aspek regulasi dan pelaksanannya. Sehingga negara akan dipaksa menjadi akuntabel dan transparan untuk mampu mengoptimalkan potensi dan kekuatannya di tengah kompetisi pasar yang sangat ketat.

Persepsi tentang relasi tingginya GDP dan kualitas pemberantasan korupsi itu seolah juga mengkonfirmasi persepsi lama bahwa sukses dan tidaknya agenda pemberantasan korupsi sangat terkait dengan kualitas pembangunan ekonomi suatu negara. Semakin kuat perekonomian suatu negara, maka semakin rendah tingkat korupsinya. Pada saat yang sama, pembangunan ekonomi tidak bisa berjalan sendiri tanpa diimbangi oleh pembangunan politik yang mapan, yang mampu menghadirkan stabilitas dan atmosfer ekonomi yang kondusif. Karena itu, resep kebijakan yang seringkali ditawarkan World Bank, USAID, dan IMF kepada negara-negara miskin dan berkembang untuk menghadapi problem korupsi dan tata kelola pemerintahannya adalah dengan menerapkan paket kebijakan liberalisasi pasar dan demokratisasi.

Pendapat lain yang berbeda tetapi memiliki arah yang relatif sama disampaikan oleh Sun dan Johnston, ${ }^{24}$ yang menyatakan bahwa efektivitas gerakan antikorupsi sangat bergantung pada pembangunan ekonomi, yang dapat menawarkan alternatif-alternatif tindakan ekonomi baru yang berguna untuk mengeliminasi korupsi. Sun dan Johnston menyarankan bahwa untuk mencapai tujuan antikorupsi dan meningkatkan kualitas pemerintahan, negara harus membangun perekonomiannya terlebih dahulu, baru kemudian kualitas demokrasi akan mengikuti belakangan. ${ }^{25}$ Sebagai bukti, para peneliti menggunakan studi kasus demokrasi di India yang telah berjalan lebih dari 50 tahun, tetapi terbukti tidak efektif dalam memberantas korupsi. Sebaliknya, sistem politik di China yang cenderung otoriter justru lebih agresif dalam menekan angka korupsinya dibanding India. Para peneliti meyakini bahwa di negara-negara yang kondisi

\footnotetext{
24Yan Sun and Michael Johnston, "Does Democracy Check Corruption? Insights from China and India”, Comparative Politics, Vol. 42 No. 1, October 2009, h. 1-19.

25Ibid., h. 16.
}

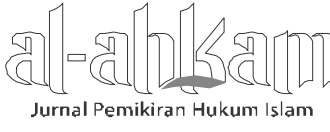


perekonomiannya lemah, sistem politiknya tidak akan bisa berjalan optimal dalam mendorong efektivitas strategi pemberantasan korupsi. Sebaliknya, perekonomian negara yang lemah itu justru akan mendorong terciptanya pola korupsi yang mudah menyebar hingga ke akar rumput, terfragmentasi dan sangat mengganggu stabilitas politik dan masa depan perekonomian bangsa. ${ }^{26}$

Tanpa keseimbangan antara pembangunan ekonomi dan pembangunan politik, korupsi akan semakin menggurita. Huntington mengatakan bahwa keseimbangan antara pembangunan politik dan ekonomi merupakan salah satu faktor kunci dalam keberhasilan mencegah korupsi. ${ }^{27}$ Dia juga menggarisbawahi bahwa keberhasilan pengendalian korupsi bukan hanya ditentukan oleh sekadar ada dan tidaknya demokrasi dalam tata perpolitikan suatu negara, melainkan lebih ditentukan oleh proses interaksi antara elemen politik, aparat negara, masyarakat, pasar, dan lainnya. Demokrasi memang bisa menghalau korupsi jika dikelola dengan bertanggung jawab. Hal itu mensyaratkan adanya para elit yang amanah dan responsif terhadap aspirasi publik, akses politik yang terbuka bagi semua pihak, serta adanya kesamaan kesempatan bagi seluruh elemen sosial-politik untuk mewarnai proses pengambilan kebijakan publik.

Tentu argumentasi-argumentasi itu masih tetap dapat diperdebatkan, termasuk pula data-data indeks persepsi korupsi (IPK) sendiri yang juga tak luput dari kritikan. Memang tidak mudah menilai kualitas pemberantasan korupsi di suatu negara, termasuk mengukur tingkat korupsi di negara-negara yang ada. Sebagian pihak misalnya merasa terlalu absurd bagi kita untuk menyandarkan tingkat korupsi dan penilaian keberhasilan pemberantasan korupsi pada data-data numerik seperti Indeks Persepsi Korupsi (IPK) semata, mengingat secara metodologis, Indeks Persepsi Korupsi ini mayoritas dibangun di atas perspesi para pelaku bisnis, di mana perubahan di sektor keuangan dan perdagangan global menjadi basis utama pengambilan data. Pengukuran semacam ini juga dianggap cenderung menafikan aspek supremasi hukum dan perbaikan sistem politik yang selama ini dianggap sebagai 'akar tunggang' praktik korupsi, di mana persilangan kepentingan antara partai politik, pebisnis, dan aparat penegak hukum dibiarkan leluasa berkelindan hingga melanggengkan lingkaran setan korupsi (vicious circle of corruption) yang tak ber-

\footnotetext{
26Ibid., h. 13.

${ }^{27}$ Samuel Huntington, Political Order in Changing Societies (New Haven, CT: Yale University Press, 1968), h. 59-71.
}

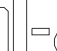

Jurnal Pemikiran Hukum Islam 
kesudahan. Kompleksitas perdebatan itu sementara dapat diselesaikan dengan refleksi masing-masing pihak untuk mencari alternatif metodologi untuk merumuskan formula baru dalam pengukuran indeks korupsi dan indeks keberhasilan agenda pemberantasan korupsi di negara-negara di dunia.

\section{Mengapa 'Islam' tidak Hadir di Negara-negara Islam?}

Pertanyaan dalam sub-bab tersebut diatas tentu mengingatkan kita para penelitian bertajuk 'How Islamic are Islamic Countries?' yang digarap oleh Scheherazade S. Rehman dan Hossein Askari dari The George Washington University sebagai penelitian yang dirancang untuk mengukur tingkat pengaruh ajaran keislaman dalam kehidupan bernegara dan bermasyarakat itu berhasil membuat publik tercengang. Penelitian itu didasarkan pada beberapa konsep ajaran Islam yang diterjemahkan sebagai indikator-indikator keislaman dalam lima aspek yang berbeda. Pertama, terkait ajaran Islam dan efeknya terhadap relasi seseorang dengan Tuhan dan hubungan sesama manusianya. Kedua, sistem ekonomi dan prinsip keadilan dalam kehidupan politik dan sosial kemasyarakatan. Ketiga, sistem konsitusi, hukum, dan perundang-undangan yang dijalankan pemerintahan setempat. Keempat, penghormatan dan pelaksanaan hak asasi manusia dan hak politik untuk dipilih dan memilih serta kebebasan berpendapat dan menyampaikan ekspresi. Kelima, ajaran keislaman yang berkaitan dengan konteks hubungan internasional dan masyarakat non-Muslim di masing-masing negara. Kelima indikator itu selanjutnya digunakan untuk mengukur tingkat keberislaman 56 negara anggota Organisasi Kerja Sama Islam (OKI) yang rata-rata berada di urutan 139 dari total sebanyak 208 negara yang disurvei. ${ }^{28}$

Hasil penelitian tersebut bahwa peringkat pertama hingga 37 ditempati oleh negara-negara berlatar belakang budaya Barat. Malaysia sebagai wakil dari negara berlatar belakang Islam ter-Islami baru mampu menduduki peringkat ke-38. Peringkat pertama diduduk oleh Irlandia, disusul negara-negara Skandinavia seperti Denmark, Luxemburg, Swedia, lalu Inggris, New Zealand, Singapura dan seterusnya. Sementara negara-negara OKI berada pada posisi setelah Malaysia yang berada di posisi ke-38, yakni Kuwait (48), Uni Emirat Arab (66), Maroko (119), Arab Saudi (131), Indonesia (140), Pakistan (147), dan terburuk adalah Somalia (206).

\footnotetext{
${ }^{28}$ Scheherazade S. Rehman dan Hossein Askari "How Islamic are Islamic Countries", Global Economy Journal, Vol. 10 No. 3, 2010.

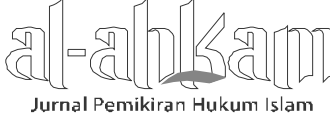


Penelitian Rehman dan Askari tersebut tampaknya akan menemukan penegasan yang serupa ketika fokus pertanyaan sedikit digeser menjadi: "Seberapa besarkah pengaruh nilai-nilai keislaman dalam upaya pemberantasan korupsi di negara dan masyarakat Anda?" Jika mengaca pada Corruption Perception Index atau IPK, negaranegara berbasis umat Islam mayoritas menduduki peringkat rendah sebagai tanda tingginya praktik korupsi di negara-negara tersebut. Terlepas dari perdebatan apakah negara-negara berbasis umat Islam itu memiliki tingkat keterlibatan yang tinggi terhadap sistem perdagangan global atau tidak, tetapi fakta menunjukkan bahwa tingginya tingkat kepercayaan masyarakat Muslim terhadap agamanya tidak dibarengi dengan out put perilaku yang sesuai dengan ajaran tersebut. Jika secara konseptual dan ajaran spiritual keislaman jelas menunjukkan pertentangannya dengan watak korupsi, maka trend yang muncul di sejumlah negara-negara Islam justru sebaliknya, korupsi terjadi secara sistemik, terstruktur dan massif. Karena itu, pertanyaan dalam sub-judul di atas menemukan relevansinya: mengapa Islam tidak hadir di negara-negara Islam? Atau lebih tepatnya dalam konteks pemberantasan korupsi, mengapa korupsi menjadi fenomena lazim alias banal di negara-negara Islam yang notabene percaya dan memegang teguh prinsip-prinsip keislaman?

Setidaknya terdapat beberapa varian alasan yang dapat disodorkan sebagai alternatif jawaban untuk merespon pertanyaan tersebut. Pertama, sistem politik negara-negara Islam tidak memberi ruang kepada hukum untuk menjadi panglima dalam pembangunan negara. Kedua, pengaruh budaya lokal terhadap pencampuran nilai-nilai koruptif dengan nilai-nilai sosial keagamaan hingga mengaburkan praktik korupsi itu sendiri di tengah masyarakat. Ketiga, terbatasnya perhatian masyarakat dan lembaga-lembaga keislaman terhadap urusan publik akibat terlalu fokus pada urusan ritual-simbolik. Ketiga alternatif jawaban itu akan dijabarkan sebagai berikut.

\section{Politik Menggantikan Hukum sebagai Panglima dalam Pembangunan}

Tidak sedikit negara-negara berpenduduk umat Islam yang berkeyakinan bahwa Islam harus diformalisasikan dalam wujud struktur pemerintahan dan tatanan hukum yang melingkupinya. Sepeninggal Nabi Muhammad ibn Abdullah ibn Abdul Mutthalib ibn Hasyim di Madinah, pada 8 Juni 632, dialektika dan perdebatan konsep kepemimpinan dalam Islam mulai dikontestasikan. Islam yang acapkali dipahami sebagai konsep integral antara agama (al-dīn) dan negara (dawlah) memunculkan berbagai tafsir politik (siyāsah) yang melahirkan beragam varian sistem politik dan pemerintahan dalam konteks dunia Islam kontemporer.

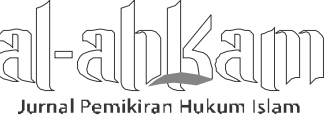


Karena itu, ketika persoalan korupsi mengakar hingga melahirkan problematika kemiskinan, instabilitas politik, keterpurukan ekonomi, konflik saudara, keterbelakangan pendidikan, dan terpuruknya kualitas lingkungan dan kesehatan, ${ }^{29}$ tidak sedikit di antara kelompok-kelompok kepentingan yang mengajukan "Islam" sebagai solusi karena dianggap sebagai ajaran yang șālị̣ li kulli zamān wa makān. Kendati demikian, perbedaan madzhab, tafsir, dan cara pandang keberislaman membuat negara-negara berbasis Muslim itu memiliki konsensus berbeda-beda di setiap masing-masing negara.

Saudi Arabia yang dikenal sebagai negeri asal Islam dilahirkan menjalankan sistem monarki (al-Mamlakah al-'Arābiyyah al-Su'ūdiyyah) dimana raja memiliki otoritas tertinggi dalam sistem pemerintahan yang dilandaskan pada al-Qur'an dan sunnah sebagai konstistusi negara dan Syariah Islam sebagai hukum dasarnya. Selaku pemegang otoritas tertinggi, Raja memiliki hak untuk menafsirkan hukum Islam dengan tetap mengakomodasi mekanisme konsultasi dan konsensus dengan sejumlah unsur negara lainnya seperti Ulama, Dewan Menteri, Dewan Konsultatif dan Pengadilan. Sementara itu, Bahrain yang menggunakan sistem monarki memilih mengadopsi sistem monarki konstitusional, dimana raja berfungsi sebagai kepala negara sekaligus kepala pemerintahan, tetapi kinerja pemerintahan seharihari dilaksanakan oleh Dewan Menteri yang dipimpin oleh Perdana Menteri. Berbeda dengan Iran yang menggunakan model negara republik Islam yang dipimpin oleh Supreme Leader Ayatullāh 'Alī Khumaynī yang membawahi angkatan bersenjata, peradilan, dan juga Guardian Council, sebuah lembaga yang melakukan rekruitmen dan pengawasan terhadap Presiden yang memimpin Dewan Menteri. Sementara di Iraq, sistem parlementer dipilih untuk mengelola 18 muzāfah atau gubernuran ditambah satu pemerintahan lokal yang khusus dikelola oleh suku Kurdi.

Sedangkan Uni Emirat Arab, Kuwait, Oman, Jordania, dan Qatar sendiri memilih sistem monarki atau monarki konstitusional dengan jenis pemerintahan parlementer. Sedangkan Palestina, Syuriah, Yaman, Turki dan Lebanon menjalankan model republik sebagai konsekuensi logis atas etnis dan keberagamaan yang multi-varian, dengan sistem pemerintahan presidensial maupun parlementer. Sementara itu, wajah politik Islam lebih kaya lagi ketika penelusuran ini dilanjut-

${ }^{29}$ P. Sweeney, "The World Bank battles the cancer of corruption", Global finance, Vol. 13 No. 10, 1999. Lih. A. Offermans, "Integrity from within", in US Department of State (ed.), The Role of FaithBased Organizations in the Struggle Against Corruption, 2001.

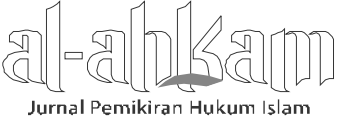


kan di luar zona Timur Tengah. Misalnya Mesir, sebuah negara yang terletak di wilayah Afrika bagian timur laut itu justru lebih memilih sistem "gado-gado" dengan identitas sistem semi-presidential multi-partai, dimana kekuasaan eksekutif dijalankan oleh presiden dan perdana menteri, tetapi realitasnya presiden memegang otoritas tertinggi. Meskipun presiden dipilih dengan sistem demokrasi, tetapi supremasi militer tetap mendominasi kekuasaan sipil. Adapun di belahan Asia Tenggara, Indonesia, Malaysia, dan Brunei Darussalam yang berdekatan juga memiliki sistem politik yang jauh berbeda. Jika Malaysia memilih sistem monarki konstitutional, maka Brunei Darussalam menjatuhkan pilihan pada sistem monarki absolut. Kedua negara persemakmuran Inggris yang menggunakan simbol dan identitas negara Islam itu juga jauh berbeda dengan Indonesia, negara dengan jumlah populasi Muslim terbanyak di dunia yang mengedepankan corak demokrasi Pancasila dan menjalankan sistem presidensial tetapi dengan sistem multipartai yang akibatnya cita-rasanya cenderung parlementer.

Ragam perbedaan sistem politik dari negara-negara yang mayoritas berpenduduk Muslim itu merupakan ijtihad sekaligus tafsir masing-masing masyarakat Muslim yang dikontekstualisasikan pada corak, karakter, demografi politik, serta kalkulasi kepentingan yang berkembang di masing-masing wilayah. Perbedaan yang sangat mencolok itu semakin meneguhkan keyakinan bahwa tawaran konsep khilāfah Islāmiyyah merupakan utopia yang sulit terwujud.

Terlepas apapun sistem politik dan corak konstitusi yang dijalankan oleh masing-masing negara tersebut, namun satu hal yang dapat digarisbawahi bahwa maraknya praktik korupsi di negara-negara tersebut mengindikasikan tidak hadirnya sistem kekuasaan yang menjamin tegaknya tatanan hukum di masingmasing negara. Dalam sebuah fase transisi, hukum harus menjadi panglima bagi setiap tata pelaksanaan kekuasaan yang ada dalam sebuah negara. Hukum tidak sepatutnya dinegosiasikan dan dikompromikan sesuai dengan kepentingan penguasa. Penguasa harus menunjukkan komitmennya di hadapan masyarakat untuk tunduk di mata hukum. Jika hukum dipaksa tunduk kepada kekuatan politik, maka instabilitas dan kekacauan dalam tata kelola pemerintahan akan terjadi. ${ }^{30} \mathrm{Di}$ situlah, kekuasaan yang tidak terkontrol akan cenderung melahirkan praktik korupsi yang sistematis dan terstruktur dalam sebuah negara.

${ }^{30} \mathrm{~A}$. M. Kjaer, "Governance in Comparative Politics II: Theories of Democratization", in Governance (Cambridge: Polity Press, 2004), h. 158.

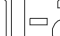

Jurnal Pemikiran Hukum Islam 
Apapun sistem politiknya, jika mampu menjamin tegaknya hukum secara adil dipercaya akan mampu menekan praktik korupsi yang ada. Sebaliknya, sedemokratis apapun suatu negara, jika sistem demokrasi yang berjalan tidak mampu menjamin tegaknya hukum, maka chaos akan muncul dimana-mana. Hal itu dibuktikan oleh banyaknya negara-negara Muslim yang belakangan menjalankan sistem demokrasi seiring dengan berakhirnya perdebatan lama tentang kesesuaian (compatibility) antara Islam dan demokrasi. ${ }^{31}$ Islam sebagai payung besar diposisikan membawahi negara, dimana sistem demokrasi yang mensyaratkan adanya partisipasi publik, keadilan hukum dan kebebasan berpendapat itu dapat mengangkat marwah Islam sebagai agama totalitas yang padu guna memecahkan problematika kehidupan, baik masalah sosial, ekonomi, politik, hingga kebudayaan. Kendati demikian, kualitas demokrasi di masing-masing negara tetap menjadi perdebatan besar. Supremasi hukum dipaksa untuk menyesuaikan diri terhadap pemegang otoritas kekuasaan. Hasilnya, korupsi semakin menjadi di tengah maraknya simbol-simbol keislaman yang betebaran dalam pelaksanaan roda pemerintahan sehari-hari.

Contoh konkret dari fenomena itu terjadi di Saudi Arabia, sebuah negara Islam yang terkenal ketat akan hukum syariahnya, dimana al-Qur'an diposisikan sebagai konstitusi tertinggi negara untuk menjamin hadirnya keadilan di tengah-tengah masyarakat dan pelaksanaan tata kelola pemerintahan yang ada. Tetapi yang terjadi, masih juga banyak oknum yang berani dan leluasa melakukan tindakan pidana korupsi di segala bidang terutama yang berhubungan dengan proyek infrastuktur pemerintahan. Raja Abdullah merespon situasi itu dengan serius, dengan cara meminta kerja sama dengan semua jajaran serta rakyat untuk terlibat langsung dalam pemberantasan korupsi. Namun demikian, suara miring tetap terdengar ketika praktik-praktik korup itu dilakukan oleh mereka yang memiliki aspek kedekatan dengan pihak kerajaan. Hampir dapat dipastikan, pedang keadilan dan tangan hukum akan kesulitan untuk menyentuh mereka.

\footnotetext{
${ }^{31}$ Bahtiar Effendy, Islam dan Negara: Transformasi Pemikiran dan Praktik Politik Islam di Indonesia" (Jakarta: Penerbit Paramadina, 1998). Lihat Ahmad Syafii Maarif, Islam as the Basis of State: A Study of the Islamic Political Ideas as Reflected in the Constituent Assembly Debates in Indonesia (Chicago: University of Chicago, 1983). Lihat Fazlur Rahman, Islam and Modernity: Transformation of an Intellectual Tradition (Chicago and London: University of Chicago Press, 1982). Lihat Marshal Hodgson, The Venture of Islam: Conscience and History in a World of Civilization, Volume1-III (Chicago: University of Chicago Press, 1974). Lih. Leonard Binder, Religion and Politics in Pakistan (Berkeley and Los Angeles: University of California Press, 1963).
} 


\section{Percampuran Nilai-nilai Koruptif dengan Nilai-nilai Sosial Keagamaan}

Dalam penelitiannya, Rose Ackerman dan Bardhan, ${ }^{32}$ pernah mempertanyakan trend yang acap bermunculan di sejumlah negara demokrasi baru di kawasan Asia. Mengapa banyak penguasa pemerintahan, politisi serta partai politik yang jelas-jelas diketahui korup tetapi masih juga mendapatkan tingkat keterpilihan dan dukungan publik yang tinggi di pemilu selanjutnya? Tidakkah ada sanksi politik publik melalui mekanisme demokrasi yang memfasilitasi rakyat untuk melakukan perubahan dan menyingkirkan para penguasa korup di kekuasaan? Apakah fenomena itu mengindikasikan bahwa masyarakat di Asia cenderung dapat menerima hadirnya praktik-praktik korupsi di lingkungan sosial di sekitar mereka?

Jawaban pertanyaan itu ternyata melingkupi aspek sosial budaya masyarakat Asia yang dinilai cenderung bisa mentoleransi praktik korupsi yang terjadi di sekitarnya. Tindakan korupsi itu dianggap telah bercampur dan membaur dengan sistem budaya yang sarat dengan muatan nilai-nilai sosial agama masyarakatnya. Dengan legitimasi etik tersebut, menjadi lazim jika kemudian tidak muncul sentimen negatif dari publik terhadap figur atau lembaga-lembaga politik yang memproduksi tindakan korupsi di sekitarnya. Sebagai contoh, pemberian sesuatu dari bawahan terhadap atasan yang acap dipersepsikan suap atau gratifikasi dalam budaya masyarakat Barat misalnya, seringkali dimaknai sebagai bentuk penghormatan dalam tradisi masyarakat Asia.

Tidak terkecuali di Indonesia, pencampuradukan sistem nilai budaya dengan prinsip-prinsip korupsi seolah telah menyatu dalam keseharian bangsa. Perilaku suap, misalnya, tidak lagi melulu ditampilkan secara eksplisit melalui penyerahan uang sebagaimana dalam sistem pertukaran ekonomi. Saat ini, praktek suap telah bertransformasi ke dalam bentuk dan nama-nama baru yang jauh lebih terhormat, religius, dan bermartabat. Misalnya praktik money politics yang diserahkan Parpol dan politisi kepada para pemuka agama, tokoh adat, dan lembaga-lembaga sosial maupun keagamaan sebagai agenda penjaringan vote getters misalnya, dengan leluasa dilakukan atas nama hibah, hadiyah, bisharah, shahriyah, atau bahkan infäq dan șadaqah, khususnya yang ditujukan kepada kelompok-kelompok miskin dan marginal. Kuatnya legitimasi moral budaya terhadap tindakan itu, hingga meng-

\footnotetext{
${ }^{32}$ Susan Rose-Ackerman, Corruption and Government: Causes, Consequences and Reform, New York, Cambridge University Press, 1999. Lih. Pranab Bardhan, "Corruption and Development: A Review of Isssues", Journal of Economic Literature, XXXV, September 1997, h. 1320-46.
}

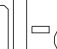

Jurnal Pemikiran Hukum Islam 
inspirasi sejumlah nama besar di negeri ini untuk mengiklankan kegiatan itu melalui media agar mendapatkan simpati politik publik secara luas.

Suap telah dikemas sedemikian rupa dengan sampul budaya dan nilai-nilai agama hingga mengaburkan substansi yang menjadi motivasi dasar tindakannya. Sejak awal, Heidenheimer pernah menegaskan bahwa telah terjadi pencampuradukan nilai-nilai koruptif dengan nuansa moral-etik dalam kehidupan masyarakat kontemporer. ${ }^{33}$ Karena semakin banyak pertukaran korupsi, maka ia semakin mirip dengan pertukaran sosial pada umumnya. Sehingga kompleksitas makna dalam jejaring interaksi sosial akan semakin mengaburkan makna sejati di balik realitas pertukaran korupsi itu sendiri. Karena itu, tidak berlebihan ketika salah seorang proklamator Indonesia Mohammad Hatta yang saat itu juga menjadi ketua Komisi Anti-Korupsi (KAK) di era awal Suharto berkuasa mengatakan bahwa "korupsi di Indonesia bukan sekadar kelemahan administrasi kenegaraan, melainkan sudah mengakar kuat dalam tradisi masyarakat kita di Indonesia".

Dalam kondisi semacam itu, korupsi tidak lagi dilakukan dalam ruang tertutup dan sembunyi-sembunyi, melainkan dijalankan di ruang terbuka, dengan perasaan bangga, dan penuh suka cita. Praktik semacam itu akan terus direproduksi, dijalankan secara intensif, dengan prinsip "tahu sama tahu" dan disertai rasa saling percaya yang sejajar di antara politisi dan masyarakatnya. Interaksi timbal balik yang dijalankan itu menjadi sulit dipangkas karena hukum ketertarikan dan sifat saling menguntungkan (reciprocity) menjadi ruh di dalamnya. Di sinilah korupsi menampakkan fungsinya sebagai media pertukaran yang "sah" secara budaya, yang identik dengan prototipe transaksi ekonomi yang berpijak pada kontrak resmi berisi besaran harga dan kewajiban-kewajiban khusus yang hendak dipertukarkan.

Jadi, budaya suap dan korupsi yang terus bermunculan sejatinya bukan semata-mata akibat dari lemahnya supremasi hukum, melainkan akibat dari kesepakatan kolektif di masyarakat hingga tercipta subkultur yang menyimpang. 'Korupsi berjamaah' merupakan terminologi menarik yang sering dipakai untuk menjelaskan fenomena tersebut. Akibatnya, upaya memberantas korupsi politik di akar rumput, yang dalam wujud sederhananya dipraktikkan dalam bentuk politik uang, pembagian sembako, bantuan sosial dan lain sebagainya itu, menjadi sulit terlaksana. Realitas inilah yang melanggengkan praktik politik dagang sapi dan jual beli suara yang secara nyata mengkhianati prinsip dasar demokrasi.

\footnotetext{
${ }^{33}$ Heidenheimer, "Korupsi dan Kekuasaan" dalam, Mohtar Lubis dan James Schott, Korupsi Politik (Jakarta: Yayasan Obor Indonesia, 1993).
} 
Di sinilah letak kesalahan fatal partai politik dan juga masih lemahnya peran civil society di negeri ini terhadap kurangnya pendidikan politik dan anti korupsi kepada publik. Penggunaan money politics merupakan jalan pintas akibat macetnya program dan visi partai politik. Seluruh elemen civil society harus terus bergerak secara intensif untuk memberikan pencerahan kepada publik agar rakyat tidak terus terperdaya, dan pesta demokrasi yang berjalan tidak hanya memfasilitasi para aktoraktor lama yang terus berusaha mempertahankan jabatan dan kekuasaan yang dinikmatinya, tanpa membawa perubahan mendasar dan faedah yang signifikan bagi rakyatnya. Jika itu yang terjadi, maka demokrasi hanya akan bermuara pada aspek partisipasi, tanpa mampu menyentuh prinsip akuntabilitas dan transparansi demi terciptanya tata kelola pemerintahan yang baik dan bersih di negeri ini.

\section{Terlalu Berorientasi pada Wilayah Ritual-simbolik}

Di tengah arus modernisasi, kehidupan beragama masyarakat kontemporer cenderung dijalankan tanpa penghayatan nilai-nilai spiritual yang mendalam dan memadai, terutama di negara-negara yang tidak menempatkan agama sebagai aturan legal formal, akibatnya agama lebih diposisikan sebagai imbauan dan seruan moral yang bersifat tidak mengikat. Di sisi lain, pelaksanaan formalisasi syariat Islam yang dijalankan di sejumlah negara Muslim juga menghadirkan persoalan-persoalan baru tentang pertentangan madzhab, pemikiran, hingga ketidakadilan dalam proses peradilannya. Agama tidak lagi menjadi cara hidup (way of life) melainkan lebih cenderung menjadi gaya hidup (life style). Kesalehan seseorang tidak lagi diukur dari integritas, kejujuran, dan komitmen untuk berbuat adil, melainkan lebih diukur dengan penggunaan atribut-atribut Arab, banyaknya penghafalan ayat al-Qur'an yang miskin pemaknaan, penghayatan dan pelaksanaan.

Akibatnya, para koruptor belakangan ini tidak lagi dilakukan oleh para aktor yang berasal dari kalangan 'abangan', sekuler, tidak paham agama yang menitikberatkan pada akhlāq al-karimmah dan konsep istiqāmah serta integritas dalam kehidupan sehari-hari. Sebaliknya, korupsi di negara-negara Muslim itu justru melibatkan banyak aktor yang 'alim, berpendidikan tinggi, paham betul seluk-beluk keislaman, bergelar pendidikan Islam di Timur Tengah, berperangai santun dan terkesan berakhlaq mulia. Untuk kasus di Indonesia, hampir susah mencari koruptor beragama Islam yang tidak naik haji. Hampir semua koruptor sudah pernah naik haji yang ditujukan untuk menyempurnakan keislamannya. Tetapi yang terjadi, para koruptor di Indonesia melakukan tindakan korupsi apa saja, mulai dari kasus "sapi", 
proyek-proyek infrastuktur pembangunan gedung, pengadaan alat dan barang, termasuk pula mengkorupsi uang haji, pengadaan al-Qur'an, dan lain sebagainya.

Sifat tamak telah membuat para koruptor itu gelap mata. Semua aturan ditabrak dan semua kekayaan hendak dikuasainya. Apa yang terjadi di Tunisia dapat dijadikan contoh konkrit dari ketamakan di mana nilai-nilai spiritual Islam hanya menjadi hiasan puja-puji yang hampa makna dan miskin penghayatan. Pada Januari 2011, Presiden Tunisia Zine el-Abidin Ben Ali yang telah berkuasa selama 23 tahun akhirnya terpaksa mundur dan melarikan diri ke Arab Saudi setelah tekanan politik rakyat tidak terbendung. Rakyat Tunisia menuding Presiden Ben Ali telah mengkhianati mereka dengan melakukan korupsi dalam jumlah yang sangat mencengangkan. Contoh kecil perilaku korup Ben Ali itu dibuktikan oleh ditemukannya timbunan harta karun yang disimpannya di balik rak buku kantor kepresidenan Tunisia yang berisi uang tunai dolar, euro, dan mata uang lainnya, juga perhiasan emas, batu zamrud, dan lainnya. Istri Ben Ali, Leila Trabelsi, juga dituduh melakukan penggelapan emas batangan milik negara senilai triliunan rupiah. Fenomena ini kemudian meluas hingga melahirkan gerakan protes dan demokratisasi di negara-negara Islam di Timur Tengah yang kemudian dikenal sebagai fenomena Arab Spring (al-Rabï' al-'Arabī) pada awal 2011 lalu.

\section{Kesimpulan}

Beberapa hal dapat disimpulkan di akhir tulisan ini, pertama, pengaruh agama terhadap tinggi atau rendahnya praktik korupsi di suatu negara merupakan persoalan kompleks yang tidak mudah untuk diukur secara numeric. Banyak sekali variabel-variabel yang mempengaruhi mengapa suatu negara yang sangat kuat pengaruh agamanya tetapi tingkat korupsinya tinggi, sementara negara lain yang tidak begitu kuat pengaruh agamanya justru memiliki tingkat korupsi yang relatif rendah. Negara-negara Skandinavia seperti Finlandia, Swiss, Denmark, dan lainnya dikenal sebagai negara dengan tingkat pengaruh agamanya relatif minim, tetapi mereka memiliki tingkat korupsi yang rendah. Artinya, agama bukanlah faktor tunggal yang mempengaruhi perilaku masyarakat dalam negara se-agamis apapun masyarakat negara itu. Ke depan, hal ini dapat menjadi pengingat bagi kita semua bahwa Islam sebagai agama yang seringkali ditawarkan sebagai solusi absolut untuk memecah beragam persoalan termasuk korupsi, hendaknya ditafsirkan dalam konteks yang lebih konkrit, membumi, dan riil dalam kehidupan sehari-hari.

Kedua, gejala tentang tingginya kepercayaan terhadap agama yang tidak dibarengi dengan konsistensi sikap yang agamis, berintegritas, jujur dan bermoral 
itu menunjukkan adanya kecenderungan menurunnya kualitas aspek kepercayaan terhadap agama itu sendiri. Komitmen keberagamaan hanya ditampilkan dalam ornamen-ornamen kegiatan sosial keseharian tetapi tidak masuk menjadi prinsipprinsip dan cara hidup masyarakat dan bernegara. Sehingga fenomena ketidakjujuran, lemahnya integritas, maraknya gaya hidup hedonis, lemahnya keteladanan dan komitmen moral, serta akutnya praktik ketidakadilan dapat berjalan beriringan dengan maraknya pengajian rutin, pagelaran majelis taklim, dan penggunaan simbol-simbol keagamaan di ranah publik.

Dalam konteks inilah, upaya merevitalisasi peran agama kembali menjadi penting untuk disuarakan. Masyarakat beragama dan organisasi-organisasi sosial keagamaan harus mempertegas posisinya dalam perang jihad melawan korupsi. Komitmen jihad melawan korupsi itu harus didasarkan pada penghayatan yang mendalam terhadap nilai-nilai spiritualitas keislaman yang menentang gaya hidup hedonis, tamak, dan tidak berintegritas. Jika penghayatan itu telah matang dilakukan, upaya-upaya pencegahan praktik korupsi tidak hanya menjadi "proyek sampingan" para lembaga-lembaga organisasi sosial keagamaan yang bekalangan ditunggangi banyak pihak yang mencari hidup dari isu-isu strategis pemberantasan korupsi. Ormas keagamaan harus steril dari kepentingan-kepentingan sempit untuk menyukseskan kampanye anti-korupsi ini. Selanjutnya, masyarakat beragama dan ormas keagamaan dapat menjadi motor penjaga moral sekaligus pressure groups bagi para pemegang otoritas di pemerintahan yang ada. Semakin tinggi otoritas moral suatu kelompok, semakin tinggi pula bobot politik yang dapat digebrakkan kepada kelompok-kelompok kepentingan yang sikap dan perilakunya tidak sesuai dengan prinsip-prinsip anti-korupsi.[a]

\section{DAFTAR PUSTAKA}

Alatas, Syed Hussein, Corruption: Its Nature, Causes and Consequences, Avebury: Aldershot and Brookfield VT, 1990.

Anderson, Christopher J. and Yuliya V. Tverdova, "Corruption, Political Allegiances, and Attitudes toward Government in Contemporary Democracies", American Journal of Political Science, Vol. 47 No. 1, January 2003.

Azra, Azumardy, "Islam, Corruption, Good Governance, and Civil Society: The Indonesian Experience”, Pluto Journals, 2007.

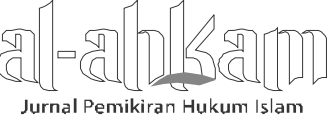


Ahmad Khoirul Umam

Bardhan, Pranab, "Corruption and Development: A Review of Isssues”, Journal of Economic Literature XXXV, September 1997., pp. 1320-46.

Beets, S. Douglas, “Global Corruption and Religion: An Empirical Examination”, Journal of Global Ethics, Vol. 3 No. 1, 2007.

Binder, Leonard, Religion and Politics in Pakistan, Berkeley and Los Angeles: University of California Press, 1963.

Bowornwathana, Bidhya \& Clay G. Wescott, "Comparative Governance Reform in Asia: Democracy, Corruption and Government Trust", International Public Management Review, Vol. 8 No. 2, 2007.

Bowser, Donald, "Corruption Trust, and the Danger to Democratisation in the Former Soviet Union", in the Transition: Essays on Post Communism, ed. David Lovell, London: Ashgate Publishers, 2001.

Della Porta, Donatella, "Social Capital, Beliefs in Government and Political Corruption" in Disaffected Democracies: What's Trubling the Trilateral Countries? Eds, Susan Pharr and Robert Putnam, Princeton: Princeton University Press, 2000.

Effendy, Bahtiar, "Islam dan Negara: Transformasi Pemikiran dan Praktik Politik Islam di Indonesia”, Jakarta: Paramadina, 1998.

Ghani, Abdul ibn Ismail an-Nablusi, Hukum Suap dan Hadiah, Jakarta: Maktabah alQur'an, 2003.

Heidenheimer, "Korupsi dan Kekuasaan" dalam Lubis, Mohtar dan James Schott, Korupsi Politik, Jakarta: Yayasan Obor Indonesia, 1993.

Hodgson, Marshal, The Venture of Islam: Conscience and History in a World of Civilization, Volume1-III, Chicago: University of Chicago Press, 1974.

Holmes L., "Corruption and the Crisis of Post-Communist State", Crime, Law \& Social Change, Vol. 27, 1997.

Huntington, Samuel, Political Order in Changing Societies, New Haven CT: Yale University Press, 1968.

Jabbar, Siti Faridah Abdul, "Corruption: Delving into the Muddy Water Through the Lens of Islam", Journal of Financial Crime, Vol. 20, Issue 2, 2013.

Jain, Arvind K., “Corruption: A Review”, Journal of Economic Surveys, Vol. 15 No. 1, 2001.

Kitthananan, Amornsak, 'Developmental States and Global Neo-liberalism', in Kennett, Patricia (ed.), Governance, Globalization and Public Policy, Cheltenham: Edward Elgar, 2008.

Kjaer, A.M., "Governance in Comparative Politics II: Theories of Democratization", in Governance, Cambridge: Polity Press, 2004.

222 || Volume 24, Nomor 2, Oktober 2014

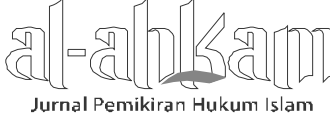


Klitgaard, R, Controlling Corruption, California: University of California Press, 2008.

Maarif, Ahmad Syafii, "Islam as the Basis of State: A Study of the Islamic Political Ideas as Reflected in the Constituent Assembly Debates in Indonesia" Chicago: University of Chicago, 1983).

Marquette, Heather, "Finding God of Moral Disegagement in the Fight Against Corruption in Developing Countries? Evidence from India and Nigeria", Public Admin. Dev, Vol.32, 2012.

Mochtar, Zainal Arifin, "Efek Treadmill Pemberantasan Korupsi”, Kompas, 11 Desember 2009.

Montinola GR and Jackman RW, "Sources of Corruption: A Cross-Counrty study", British Journal of Political Science, Vol. 31, 2002.

Offermans, A., "Integrity from within", in US Department of State (ed), The Role of Faith-Based Organizations in the Struggle Against Corruption, 2001.

Park, H., "Determinants of Corruption: A Cross-National Analysis", Multinational Business Review, Vol. 11 No. 2, 2003.

Quah, J., "Combating Corruption in the Asia-Pacific Countries: What Do We Know and What Needs to be Done?",International Public Management Review, Vol. 10 No. 1, 2009.

Rahman, Fazlur, Islam and Modernity: Transformation of an Intellectual Tradition, Chicago and London: University of Chicago Press, 1982.

Rehman, Scheherazade S. dan Hossein Askari "How Islamic are Islamic Countries”, Global Economy Journal, Vol.10 No. 3, 2010.

Rose-Ackerman, Susan, "The Political Economy of Corruption" in Kimerbly Ann Elliott (ed), Corruption and the Global Economy, Washington DC: Institute for International Economics, 1997.

Rose-Ackerman, Susan, Corruption and Government: Causes, Consequences and Reform, New York: Cambridge University Press, 1999.

Sandholtz, Wayne and William Koetzle, "Accounting for Corruption: Economic Structure, Democracy, and Trade, International Studies Quarterly, Vol. 44 No. 1, March 2000.

Seligson, Mitchell, "The Impact of Corruption on Regime Legitimacy: A Comparative Study of Four Latin American Countries", Journal of Politics, Vol. 64 No. 2, 2002.

Sun, Yan and Michael Johnston, "Does Democracy Check Corruption? Insights from China and India”, Comparative Politics, Vol. 42 No. 1, October 2009.

Sweeney, P., "The World Bank battles the cancer of corruption”, Global finance, Vol. 13 No. 10, 1999.

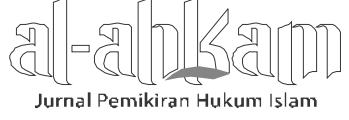


Ahmad Khoirul Umam

Tageepera R., "Baltic Values and Corruption in Comparative Contex", Journal of Baltic Studies, Vol. 33 No. 3, 2002.

Treisman, D., "The causes of corruption: A cross-national survey", Journal of Public Economics, Vol. 76 No. 3, 2000.

Tulchin, Joseph S., and Ralph H. Espach (Ed), Combating Corruption in Latin America, Washington DC: Woodrow Wilson Centre Press, 2000.

Umam, Ahmad Khoirul, Kiai dan Budaya Korupsi di Indonesia, Semarang: Rasail, 2006. 